\title{
Federal Proportionality Review in EU Law: Whose Rights are they Anyway?
}

\author{
Darren Harvey \\ Lecturer in Law, King's College London, London, UK \\ darren.harvey@kcl.ac.uk
}

\begin{abstract}
The principle of proportionality has always operated as a means of protecting individuals from excessive uses of public power. When situated alongside the principles of conferral and subsidiarity, proportionality also possesses a federal dimension. In this guise, the principle limits the intensity of EU intervention in order to protect national regulatory autonomy. This federal element of proportionality has featured in recent Court of Justice of the European Union (CJEU) cases. For example, Member States have challenged European Union (EU) legislation for imposing disproportionate social and economic costs in their particular States. This article considers whether individuals can similarly challenge EU legislation for disproportionately interfering with the regulatory autonomy of the Member States? Having considered this question from the perspective of US federalism, it is argued that individuals are actually articulating "Member States' rights" in such cases. In so doing, attention is drawn to the question of whose rights and interests are really being articulated and balanced in these disputes.
\end{abstract}

\section{Keywords}

EU law - federalism - proportionality - states' rights - judicial review

\section{Introduction}

The European Union (EU) exists as result of nation states establishing an organisation aimed at pursuing a number of shared aims and objectives. It is "an institutional arrangement, which allows for the development of a set of policies and the regulation of a broad range of economic, social and legal 
relationships". ${ }^{1}$ The foundational Treaties of the EU (today the Treaty on European Union (TEU) and the Treaty on the Functioning of the European Union (TFEU)) establish a number of EU institutions and endow them with broad legislative, regulatory and administrative powers for the purposes of achieving often open-ended, policy-oriented goals. ${ }^{2}$

At the same time, the EU is an organisation of limited powers. Founded upon the principle of conferral, the EU institutions can only act within the limits of the competences conferred upon them by the Member States in the Treaties. ${ }^{3}$ Furthermore, the exercise of EU legislative powers is curtailed by the principles of subsidiarity and proportionality. These principles essentially provide that the EU should only act when its objectives can be better achieved at EU rather than Member State level, and that such action should not go beyond what is necessary to achieve those objectives. ${ }^{4}$ When taken together, these three constitutional principles in Article $5 \mathrm{TEU}$ seek to protect the EU's "federal order of competences" by limiting the existence and exercise of the EU's law-making powers. ${ }^{5}$

There is, therefore, a fundamental tension at the heart of the EU legal order between ensuring that sufficient powers are given to the EU institutions to achieve broadly defined policy objectives, whilst simultaneously respecting the principles enshrined in Article 5 TEU. ${ }^{6}$

In analysing how the legal and political mechanisms contained in the EU Treaties have sought to manage this tension between pan-European policymaking and respecting the division of competences between the EU and its Member States, scholars have long had recourse to the tools of comparative federalism. ${ }^{7}$ Questions pertaining to the existence of EU legislative competence

1 L. Azoulai, 'The Complex Weave of Harmonization', in D. Chalmers and A. Arnull (eds.), The Oxford Handbook of European Union Law (Oxford University Press, Oxford, 2015) p. 589.

2 G. Davies, 'Democracy and Legitimacy in the Shadow of Purposive Competence', 21 European Law Journal (2015) pp. 2-22.

3 Article $5(2) \mathrm{TEU}$.

4 Articles 5(3) and (4) TEU.

5 A. Von Bogdandy and J. Bast, 'The Federal Order of Competences', in A. Von Bogdandy and J. Bast (eds.), Principles of European Constitutional Law (Hart Publishing, Oxford, 2009) p.275.

6 For an example of the EU and its Member States discussing this tension see Laeken Declaration on the Future of the European Union, Bulletin of the European Union 12 (2001) Luxembourg: Office for Official Publications of the European Communities, 'Presidency Conclusions of the Laeken European Council', (14 and 15 December 2001), SN 300/1/o1 REV 14.

7 M. Claes and M. de Visser, 'The European Court of Justice as a Federal Constitutional Court: A Comparative Perspective', in E. Cloots, G. de Baere and S. Sottiaux (eds.), Federalism in the European Union (Hart Publishing, Oxford, 2012) p.83; R. Schütze, From Dual to Cooperative Federalism: The Changing Structure of European Law (Oxford University Press 2009); K. Nicolaïdis and R. Howse (eds.), The Federal Vision: Legitimacy and Levels of Governance in the United States and the European Union (Oxford University Press, Oxford, 2001). 
to act in a given instance, the substantive legality of exercises of those EU legislative competences, and the division of law-making powers between the EU institutions themselves have all been considered through the lens of federalism. "All [such questions] refer to the problem of the coexistence of different political entities within a larger polity to which they are bound up and as such may readily be cast in 'federalist' terms."9 Indeed, it has been noted that while the EU is not a State, "there is hardly a chapter of law where its conceptual basis and its functioning are as close as to that as a federal state, as in the area of competences".10

While several different aspects of the EU's federal order of competences have long been analysed in the literature, the role that natural and legal persons play when challenging the validity of EU legislation on "federalism" grounds has seldom been considered. In particular, the extent to which individuals may be said to be articulating "Member States' rights" when challenging EU legislation on Article 5 TEU grounds has yet to be fully explored.

An enquiry of this nature is necessitated by contemporary developments in the jurisprudence of the Court of Justice of the European Union (CJEU). EU legislation has recently been challenged by Member States on the grounds that the EU legislature breached the principle of proportionality (and closely associated principle of subsidiarity) by failing to take the situation of particular Member States into account when legislating." ${ }^{11}$ Additionally, it has been argued that EU legislation is invalid for imposing disproportionate economic and social costs in terms of lost jobs and revenues in certain Member States. ${ }^{12}$ Finally, it has been suggested that EU legislation infringed the principles of federal proportionality and subsidiarity by interfering with aspects of the national identity of the Member States as protected by Article 4(2) TEU. ${ }^{13}$

In light of these novel federalism challenges to EU legislation, the question arises as to whether individuals/companies can raise similar arguments when seeking to indirectly challenge the validity of EU legislation? ${ }^{14}$ Given that most challenges to EU legislation by natural and legal persons originate in national

8 K. Lenaerts, 'Federalism and the Rule of Law: Perspectives from the European Court of Justice', 33 Fordham International Law Journal (2011) p. 1338; Von Bogdandy and Bast, supra note 5 , p. 275 .

9 L. Azoulai, 'Introduction', in L. Azoulai (ed), The Question of Competence in the European Union (Oxford University Press, Oxford, 2014) p.1.

10 Von Bogdandy and Bast, supra note 5, p. 275.

11 Case C-508/13 Estonia v. Parliament and Council, ECLI:EU:C:2015:403.

12 Case C-358/14 Poland v. European Parliament and Council, ECLI:EU:C:2016:323.

13 AG Kokott in Case C-358/14 Poland v. Parliament and Council, ECLI:EU:C:2015:848.

14 For an analysis of whose rights are being balanced in cases where the human rights of legal persons are raised, see E. Gill-Pedro, 'Proportionality and the Human Rights of Companies 
courts, might we see federalism arguments of this sort being referred to the CJEU by way of references for preliminary rulings? ${ }^{15}$ If so, how should the Court respond to the claim by an individual that EU legislation should be struck down for imposing disproportionate economic and social costs upon certain Member States? Similarly - and much more explosively - could natural or legal persons challenge EU legislation on the grounds that that legislation impermissibly encroaches upon the national constitutional identity of a Member State?

These questions go to the very heart of this special edition's enquiry into whose rights and interests are being articulated, identified and ultimately balanced (i.e. States, individuals, corporations, etc.) whenever courts have recourse to the principle of proportionality.

In contributing to this discussion, this article argues that certain challenges to EU legislation by natural and legal persons are best conceptualised as an articulation of "Member States' rights" by those parties. To this end, the article proceeds in five sections. Section 2 considers the principle of proportionality and its role in EU law. Section 3 takes a comparative approach and examines the claim that within the United States federal system individuals may actually articulate "States' rights" when challenging the constitutionality of federal legislation. These insights are then applied to the EU legal order in Sections 4 and 5 when analysing the role that individuals play in contesting EU legislation on federalism grounds. In arguing that cases of this nature represent an articulation of "Member States' rights" by individuals, attention is drawn to some of the problems that the CJEU may face when trying to identify whose rights and interests are to be balanced when conducting (federal) proportionality review of EU legislation. Section 6 provides a conclusion.

\subsection{Protecting Liberal Values}

The principle of proportionality has been referred to as "an overarching principle of constitutional adjudication, the preferred procedure for managing disputes involving an alleged conflict between two rights claims, or between a rights provision and a legitimate state or public interest". ${ }^{16}$

under the ECHR - Whose Interests Are at Stake?', 89:3-4 Nordic Journal of International Law (2020), this issue.

15 Article 267 TFEU.

16 A. Stone Sweet and J. Mathews, 'Proportionality Balancing and Global Constitutionalism', 47 Columbia Journal of Transnational Law (2008) p. 73. 
Proportionality began its life in the European Economic Community (EEC) as an unwritten general principle of law developed by the jurisprudence of the CJEU. ${ }^{17}$ Prior to the Treaty of Maastricht, the principle was utilised by the Court of Justice in order to "protect liberal values", understood as guarding the individual from excessive exercises of public power by the Community institutions. ${ }^{18}$ During the early decades of the European integration project, proportionality played a key role in cases where Community legislation was alleged to have disproportionately restricted fundamental rights of an economic nature, such as the right to property or the freedom to conduct a business. ${ }^{19}$ Moreover, proportionality was frequently utilised by the CJEU when assessing the justifications proffered by Member States for national measures that restricted the fundamental freedoms of the EU internal market. ${ }^{20}$

Today, in accordance with the EU's Charter of Fundamental Rights (CFR), the principle is widely utilised by the CJEU when reviewing whether EU legislation that restricts Charter-based rights may nevertheless be legally justified in the pursuit of objectives in the EU's general interest. ${ }^{21}$

In all such cases, the CJEU uses proportionality to scrutinise whether an EU legal act: (i) pursues a legitimate aim (suitability), (b) does not go beyond what is necessary to achieve that aim (necessity) and (c) does not impose a disproportionate or excessive burden upon the individual (proportionality stricto sensu). ${ }^{22}$ This structured proportionality examination allows the Court to scrutinise the substantive legality or merits of discretionary policy choices enacted by the EU institutions. ${ }^{23}$ However, in most proportionality cases the EU legislature enjoys a wide margin of discretion when making political, economic and social choices that often also require the undertaking of complex assessments. ${ }^{24}$ As a

17 Case 11-70 Internationale Handelsgesellschaft $m b H$ v. Einfuhr-und Vorratsstelle für Getreide und Futtermittel, ECLI:EU:C:1970:114.

18 R. Schütze, 'EU Competences', in D. Chalmers and A. Arnull (eds.), The Oxford Handbook of European Union Law (Oxford University Press, Oxford, 2015) p.96.

19 Case 4-73 J Nold, Kohlen- und Baustoffgroßhandlung v. Commission of the European Communities ECLI:EU:C:1974:51; Internationale Handelsgesellschaft, supra note 17.

20 Case 261/81 Walter Rau Lebensmittelwerke v. De Smedt PVBA, ECLI:EU:C:1982:382. See also S. Barbou des Places 'Revisiting proportionality in internal market law: Looking at the unnamed actors in the CJEU's reasoning', 89:4 Nordic Journal of International Law (2020), this issue.

21 Article 52(1) Charter of Fundamental Rights of the European Union.

22 T. Harbo, 'The Function of the Proportionality Principle in EU Law', 16 European Law Journal (2010) p. 158; For a classic judicial statement of these steps see Case C-331/88 R v. Minister for Agriculture, Fisheries and Food, exp Fedesa, ECLI:EU:C:199o:391, para. 13.

23 Paul Craig, EU Administrative Law (Oxford University Press, Oxford, 2012) ch 19.

24 Fedesa, supra note 22. 
consequence of this broad discretion, judicial review is reduced to considering whether the legislation in question is "manifestly inappropriate having regard to the objective which the competent institution is seeking to pursue". 25

\subsection{Proportionality as a Safeguard of Federalism?}

Following the entry into force of the Maastricht Treaty, the principle of proportionality was formally enshrined in the EU Treaties as a fundamental constitutional principle of the EU legal order. ${ }^{26}$ According to what is now Article 5(4) TEU, under the principle of proportionality, "the content and form of Union action shall not exceed what is necessary to achieve the objectives of the Treaties". 27

This treaty-based formulation of proportionality sits alongside the principles of conferral and subsidiarity in Articles 5(2) and 5(3) TEU respectively. Despite its long history as a general principle of Community law prior to the Maastricht Treaty, it is widely accepted that the addition of a treaty-based variant of proportionality alongside the principles of conferral and subsidiarity was intended to address increased concerns amongst the Member States about "competence creep" by the EU institutions. ${ }^{28}$

The principle of conferral deals with the existence of EU competence and provides that "the Union shall act only within the limits of the competences conferred upon it by the Member States in the Treaties to attain the objectives set out therein. Competences not conferred upon the Union in the Treaties remain with the Member States". ${ }^{29}$ In addition to the existence of EU competences, Article $5 \mathrm{TEU}$ also regulates the exercise of EU competences by the EU's legislative institutions via the principles of subsidiarity and proportionality. ${ }^{30}$ According to Article 5(3) TEU:

Under the principle of subsidiarity, in areas which do not fall within its exclusive competence, the Union shall act only if and in so far as the

25 Case C-491/or The Queen v. Secretary of State for Health, ex parte British American Tobacco (Investments) Ltd and Imperial Tobacco Ltd (BAT) ECLI:EU:C:2002:741, para. 123 and case law cited therein.

A. Dashwood, 'The Limits of European Community Powers', 21 European Law Review (1996) p. 114 .

27 Article 5(4) TEU.

28 S. Weatherill, 'Competence Creep and Competence Control', 23 Yearbook of European Law (2004) pp.1-55.

29 Article $5(2) \mathrm{TEU}$.

30 Article $5(1)$ TEU. 
objectives of the proposed action cannot be sufficiently achieved by the Member States, either at central level or at regional and local level, but can rather, by reason of the scale or effects of the proposed action, be better achieved at Union level. ${ }^{31}$

Subsidiarity is widely conceptualised as playing a vital role in navigating the EU's federal balance of competences "by setting a functional criteria to decide whether the Union - or rather the states - should act in a given field". ${ }^{32}$ In essence, it asks whether "the [Union] institutions should refrain from acting, even when constitutionally permitted to do so, if their objectives could effectively be served by action taken at or below the Member State level". ${ }^{33}$ It is for this reason that the principle has been referred to as a "constitutional safeguard of federalism that should limit the exercise of powers granted to the European Union" 34 and is "employed to safeguard the autonomy of national regulatory powers". ${ }^{35}$

By situating a treaty-based definition of proportionality alongside conferral and subsidiarity in Article 5 TEU, the principle had taken on a novel, "federal dimension" in the post-Maastricht era. ${ }^{36}$ In addition to its traditional, rights-protecting variant discussed above, proportionality as enshrined in Article 5(4) TEU was concerned with "limiting the intensity of Union intervention in order to protect national regulatory autonomy". ${ }^{37}$ It was therefore "designed to safeguard primarily the interests of the Member States vis-à-vis the Community" 38 and "operate as a constitutional tool designed to protect the Member States from an EU 'competence creep'”.39

31 Article 5(3) TEU.

32 F. Fabbrini, 'The Principle of Subsidiarity', in Schütze and Tridimas (eds.), supra note 5, p.224.

33 G.A Bermann, 'Taking Subsidiarity Seriously: Federalism in the European Community and the United States', 94 Columbia Law Review (1994) p. 334.

34 Schütze, supra note 7, p. 247; see similarly K. Lenaerts, 'The Principle of Subsidiarity and the Environment in the European Union: Keeping the Balance of Federalism', 17 Fordham International Law Journal (1993) pp. 850-851.

35 M. Kumm, 'Constitutionalising Subsidiarity in Integrated Markets: The Case of Tobacco Regulation in the European Union', 12 European Law Journal (2006) p. 518.

36 Takis Tridimas, 'The Principle of Proportionality in Community Law: From the Rule of Law to Market Integration', 31 Irish Jurist (1996) p. 99.

37 Schütze, supra note 18, p. 97.

38 Tridimas, supra note 36 , p. 99 .

39 K Lenaerts, 'The European Court of Justice and Process-Oriented Review', 31 Yearbook of European Law (2012) p.10. 
When taken together, the principles of conferral, subsidiarity and proportionality have been said to function as a crucial means of "safeguarding the federal balance of competences" between the EU and its Member States. ${ }^{40}$ Indeed, in a number of cases, we see Member States contesting the validity of EU legal acts before the CJEU on the grounds that they infringe one or more of the federalism principles enshrined in Article 5 TEU. ${ }^{41}$ In so doing, they are essentially seeking to (re)assert their right to national regulatory autonomy. ${ }^{42}$ For example, the consequence of a successful challenge to EU legislation on the grounds that a particular objective cannot be better achieved at EU level and/or could be better regulated at the national level would be the invalidation of the EU legislation concerned. With EU legislation no longer regulating the matter, Member States are then free to (re)assert their own law-making competences in the area concerned.

Against this background, the question arises as to whether individuals may contest the validity of EU legislation by claiming it has infringed the EU's federal balance of competences? More specifically, can we point to examples in the case law where natural/legal persons have used the (federal) proportionality principle to challenge EU legislation on the grounds that it has "unnecessarily restricted national autonomy?"43 If so, whose rights and interests are being articulated, identified and balanced in such disputes? Is there scope for arguing that individuals are not seeking to defend their own rights per se, but are, in effect, articulating some underlying "Member States' rights" to national regulatory autonomy?

Inspiration for these sorts of questions comes from the academic literature on the federal division of powers in the United States. Comparisons between the EU and US legal orders are not uncommon in this area. The manner in

40 Schütze, supra note 18, p. 76. Similarly, Armin Von Bogdandy refers to Title I TEU as enshrining "the founding principles of the federal relationship between the EU and its Member States". A. Von Bogdandy, 'Founding Principles of EU Law: A Theoretical and Doctrinal Sketch', 16 European Law Journal (2010) p. 106.

41 Case C-376/98 Germany v. European Parliament and Council (Tobacco Advertising One) ECLI:EU:C:2000:544.

42 E.A Young, 'Protecting Member State Autonomy in the European Union: Some Cautionary Tales from American Federalism', 77 New York University Law Review (2002) p. 1612.

43 R. Schütze, European Constitutional Law (Cambridge University Press, Cambridge, 2012) p.184. 
which power is distributed in the United States Constitution between the federal government and the States, and how this division is safeguarded by political and judicial processes, has long provided a source for comparative analysis for EU scholars. ${ }^{44}$ In particular, a number of parallels have been drawn between the safeguards of federalism in the United States and the upholding of the EU's federalism principles enshrined in Article 5 TEU. ${ }^{45}$

What has yet to be explored in any detail, however, is the role that individuals play in contesting EU legislation on federalism grounds.

The starting point for this discussion is Wechsler's seminal article on The Political Safeguards of Federalism - "among the most important articles on federalism published in ... [the 2oth] century". ${ }^{46}$ Wechsler argued that the crucial role played by the constituent States of the United States of America within the national legislative process provided the core guarantee of the federal division of powers in the Constitution. ${ }^{47}$ As Wechsler put it, "[t]he actual extent of central intervention in the governance of our affairs is determined far less by the formal power distribution than by the sheer existence of the states and their political power to influence the action of the national authority".48

In his view, the "continuous existence of the states as governmental entities and their strategic role in the selection of Congress and the President" meant that constraints upon federal action were primarily a matter for politics and not law. This emphasis upon the political process meant that "the states do not need judicial protection from expansive federal legislation, because their role in the makeup and the operation of the national government provides them with sufficient means to protect their rights". 49 "Federal intervention as against the states is thus primarily a matter for congressional determination in our

44 The powers of the US Congress are enumerated in Article 1, Section 8 of the US Constitution. Furthermore, the Xth Amendment to the Constitution provides: "The powers not delegated to the United States by the Constitution, nor prohibited by it to the States, are reserved to the States respectively, or to the people". For comparisons between the EU and the US, see E. Fahey and D. Curtin, A Transatlantic Community of Law: Legal Perspectives on the Relationship between the EU and US Legal Orders (Cambridge University Press, Cambridge, 2014); Nicolaïdis and Howse, supra note 7).

45 Claes and Visser, supra note 7, p.83; Dennis J. Edwards, 'Fearing Federalism's Failure: Subsidiarity in the European Union., 44 American Journal of Comparative Law (1996) p. 537.

46 L. D Kramer, 'Putting the Politics Back into the Political Safeguards of Federalism', 100 Columbia Law Review (2000) p. 217.

47 H. Wechsler, "The Political Safeguards of Federalism: The Role of the States in the Composition and Selection of the National Government', 54 Columbia Law Review (1954) p. 543.

48 Ibid., p. 544.

49 J. C Yoo, 'The Judicial Safeguards of Federalism', 7o Southern California Law Review (1996) p. 1312 . 
system as it stands." ${ }^{50}$ (One can draw an analogy here between Wechsler's work and the law-making process of the EEC prior to the Single European Act, where unanimity voting prevailed in the Council. This political safeguard served - in theory at least - to both protect Member State competences and reduce the need for judicial review of federalism questions by the CJEU ). ${ }^{51}$

The central tenets of Wechsler's thesis were further developed by Choper, who argued that the federal division of powers in the United States should be declared non-justiciable and thus be resolved entirely through the political process. ${ }^{52}$ Underlying Choper's thesis was the "contention that there is a qualitative difference that separates constitutional issues of federalism from those of individual liberty, a dissimilarity that augurs for the variant judicial role proposed". ${ }^{53}$ This difference does not lie in the relative difficulty or intricacy of the questions involved, but "may be described as one between issues of practicality and issues of principle". ${ }^{4}$

In Choper's view, judicial review of legislation for compliance with constitutionally protected fundamental rights was ultimately a matter of principle. Whereas short term reasons related to the will of the majority and efficient public administration may speak in favour of restricting individual rights in the pursuit of the wider public interest, "our historic ideals and our special regard for the dignity of the individual compel the collectivity to subjugate its more immediate needs to the preservation of designated individual rights". 55

This was to be contrasted with the "distinguishable species" of federalism cases, where the core contention in the dispute before the court is that the federal government has legislated beyond the scope of its powers under the constitution. ${ }^{56}$ Here, the constitutional issue raised is "wholly different" from the claim that governmental action infringes a fundamental right or liberty protected by the Constitution. ${ }^{57}$

The essence of the individual rights claim is that no organ of government, national or state, may undertake the challenged activity. In contrast, an

$50 \quad$ Wechsler, supra note 47, p. 559 .

$5^{1}$ On this point see AG Maduro in Case C-58/08 The Queen, on the application of Vodafone Ltd and Others v. Secretary of State for Business, Enterprise and Regulatory Reform, ECLI:EU:C:2009:596.

J. H Choper, "The Scope of National Power Vis-a-Vis the States: The Dispensability of Judicial Review', 86 The Yale Law Journal (1977) p. 1552.

53 Ibid., p. 1554.

54 Ibid.

55 Ibid., p. 1555 .

56 Ibid.

57 Ibid. 
alleged constitutional violation of the federalism principle concedes that one of the two levels of government has power to engage in the questioned conduct; the issue is simply whether the particular level that has acted is the constitutionally proper one. ${ }^{58}$

As a result, "constitutional questions of federalism differ from those of individual liberty both in their distinctive, pragmatic quality and in the likelihood of their fair resolution within the national political chambers". ${ }^{59}$ For the purposes of the present enquiry, Choper's key argument is that numerous challenges brought by individuals to the constitutionality of federal legislation on federalism grounds "implicitly concedes that the challenged conduct could have been undertaken by state governments acting within their jurisdiction. Thus the attack makes no genuine constitutional claim of individual freedom." ${ }^{\prime 0}$ There is said to be an "essential difference" between striking down federal legislation for violating fundamental rights and for overstepping the bounds of federal competence. In the former case, "judicial invalidations of government action that augment the total range of individual liberty"; whereas in the latter such invalidations result only in a redistribution of power between the federal and State authorities to regulate a particular issue. ${ }^{61}$

Consequently, the core claim being articulated when individuals challenge legislation on federalism grounds is not one of individual liberty, but is really about the abridgement of States' rights or the usurpation of the regulatory autonomy of the constituent States. ${ }^{62}$ Such cases in reality entail "states' rights claims asserted by private citizens, a procedure which raises legitimate standing issues" and which should, therefore, be declared non-justiciable. ${ }^{63}$ For Choper, allowing individuals to bring (and sometimes win) States' rights challenges to federal legislation carried the risk of producing rather bizarre results: "The irony in such a [successful] challenge would be most poignant if a majority of every state's congressional representatives voted for the law in question, and if all states defend the law in the resulting litigation." ${ }^{\prime 4}$

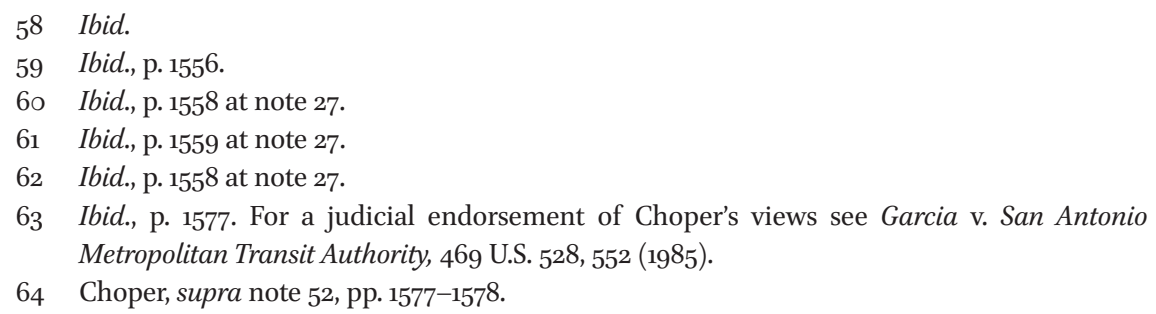


Against this background, it is contended that a comparable dynamic may be said to be in operation when individuals contest the validity of EU legislation for infringing the EU's federalism principles contained in Article 5 TEU. In a manner that is roughly analogous to Choper's thesis in the US system, the claim here is that natural and legal persons are not actually articulating some individual right or interest in such cases. Instead, where EU legislation is challenged by individuals on the grounds that it infringes the principles of (federal) proportionality and subsidiarity, the claimants are in fact articulating some conception of "Member States' rights" to continued national regulatory autonomy. ${ }^{65}$

It has long been established in EU law that natural and legal persons face near insurmountable hurdles when seeking to directly challenge EU legislation in an action for annulment before the CJEU. ${ }^{66}$ Most direct challenges to EU legislation on Article 5 TEU grounds come from the Member States themselves. ${ }^{67}$ Accordingly, the vast majority of cases in which the validity of EU legislation has been contested by individuals have come about indirectly through the preliminary reference procedure. ${ }^{68}$ By initially raising arguments about the validity of EU legal acts in national courts, individuals have on occasion succeeded in having those arguments referred by those national courts to the Court of Justice in Luxembourg. ${ }^{69}$ What is more, some of those national references for preliminary rulings have asked the CJEU to rule on whether the EU legal act at issue is invalid for infringing the EU's federalism principles. ${ }^{70}$

65 For a discussion of the ways in which subsidiarity and proportionality may be read and applied together within the context of EU federalism see X. Groussot and S. Bogojević, 'Subsidiarity as a Procedural Safeguard of Federalism', in L. Azoulai (ed), The Question of Competence in the European Union (Oxford University Press, Oxford, 2014) pp.236-237.

66 Case 25-62 Plaumann \& Co v. Commission of the European Economic Community, ECLI:EU:C:1963:17.

67 Case C-38o/o3 Germany v. European Parliament and Council, ECLI:EU:C:2006:772; Case C-377/98 Kingdom of the Netherlands v. European Parliament and Council of the European Union, ECLI:EU:C:2001:523 86.

68 Article 267 TFEU.

69 National judges are obliged to stay national proceedings and refer a question of validity to the CJEU whenever a plausible argument to that effect is raised before a national court. See C-344/o4 IATA and ELFAA, ECLI:EU:C:2006:10, para. 30.

70 Vodafone, supra note 51 ; Joined cases $C_{-154 / 04}$ and $C_{-155 / 04}$ The Queen, on the application of Alliance for Natural Health and Nutri-Link Ltd v. Secretary of State for Health, ECLI:EU:C:2005:449; British American Tobacco, supra note 25. 
Strictly speaking, it is the national court itself (and not the individuals) that articulates the specific legal grounds of challenge when making a reference for a preliminary ruling on the validity of an EU legal act. The procedure set down in Article $267 \mathrm{TFEU}$ is intended to foster equality and cooperation between national courts and the $\mathrm{CJEU}$, rather than to provide for an individual right of appeal to Luxembourg. ${ }^{71}$ One possible retort to the claim that individuals are actually articulating "Member States' rights" in such cases, therefore, is that the preliminary ruling procedure simply provides for "abstract" validity review by the CJEU. ${ }^{72}$ Like many constitutional review procedures in national legal orders, the reference to the CJEU merely asks, in abstract or general terms, whether a particular EU legal act infringes provisions of the EU Treaties and is therefore invalid. ${ }^{73}$ As such, the rights of the specific individual in the case are not directly articulated, balanced, etc. Instead, the CJEU's task is to consider whether a generally applicable piece of EU legislation is, in the abstract, incompatible with principles of the EU Treaties (e.g. Article 5 TEU).

Formally speaking this is correct: the preliminary reference procedure does not provide for an individual right to review EU legislation and the ensuing review by the CJEU is typically conducted in an abstract fashion. If one delves a little deeper, however, it is evident that natural and legal persons can and do play a key role in articulating challenges to EU legislation on federalism grounds.

A good example of this can be seen in Vodafone, where the claimants challenged the validity of an EU Regulation which imposed a price cap on wholesale and retail roaming charges that telephone companies could charge. ${ }^{74}$ In the course of proceedings before the English High Court, the claimants argued that the Regulation was invalid on the grounds that it infringed the principles of subsidiarity and proportionality. In accepting that the claimants had a plausible argument and that a reference on validity should be sent to the CJEU, the national judge noted that he would "leave the precise wording of the questions and the supporting factual statements and documents and bundles to be addressed by counsel subsequently". ${ }^{75}$ This was followed by a dialogue between the national judge and counsel for the claimants as to how best to word the subsidiarity and proportionality challenges to the EU Regulation

71 N. G Foster, Foster on EU Law (Oxford University Press, Oxford, 2019) p. 187.

72 V.F. Comella, 'The European Model of Constitutional Review of Legislation: Toward Decentralization?', 2 International Journal of Constitutional Law (2004) pp. 463-464.

73 Ibid., pp. 48o-482.

74 The Queen on the Application of Vodafone Limited and Others v. Secretary of State for Business and Regulatory Reform [2007] EWHC 3018 (Admin).

75 Ibid., para. 20. 
when sending the reference to the CJEU. ${ }^{76}$ The reference was duly drafted and sent, and the CJEU then proceeded to review the Regulation for its compliance with, inter alia, the principles of subsidiarity and proportionality. ${ }^{77}$

It is worth pausing to consider the nature of the claims being raised here. When it comes to the proportionality argument, it is clear that Vodafone is arguing that the cap on roaming charges places a disproportionate or excessive burden on their business. This is standard proportionality stuff. But consider the closely associated argument of Vodafone regarding the principle of subsidiarity, which the national judge held was arguable and indeed referred to Luxembourg.

Whose rights and interests are really being articulated here? In essence, Vodafone is arguing that the regulation of roaming charges could have been sufficiently achieved by the Member States and/or that the objectives of such regulation are not better achieved at the EU level. ${ }^{78}$ The core claim is that the subject matter should be regulated at a national and not European level. It thus constitutes an argument in favour of continued national regulatory autonomy, which, by its very nature, pertains to the federal balance of competences in the EU. As such, Choper would contend that the issue is not one of individual liberty, but, rather, "the abridgement of States' rights or the usurpation of the regulatory autonomy of the constituent States". ${ }^{79}$ In reality, it is a "Member States' rights" claim being asserted by private individuals.

Another example is Alliance for Natural Health, where certain companies who sold food supplements challenged the validity of EU legislation which harmonised Member State rules governing foods containing concentrated sources of nutrients. ${ }^{80}$ With regards to subsidiarity, the claimants argued that EU legislation unjustifiably interfered with the powers of the Member States in a sensitive area involving health, social and economic policy. Furthermore, it was contended that the Member States were best placed to determine, for their respective markets, the public health requirements capable of justifying restrictions on the free marketing of food supplements on their national territory. ${ }^{81}$

Similarly, in British American Tobacco, the claimants argued, inter alia, that EU legislation harmonising rules on the production and sale of tobacco

\footnotetext{
$76 \quad$ Ibid., paras 21-26.

77 Vodafone, supra note 51.

78 See the wording of Article 5(3) TEU.

79 Choper, supra note 52, p. 1558 at note 27.

8o Alliance for Natural Health, supra note 70.

81 Ibid., para. 100.
} 
products infringed the subsidiarity principle since "no evidence has been adduced to show that the Member States could not adopt the measures of public health protection they considered necessary". ${ }^{82}$

Based on these examples, it is certainly arguable that the claimants in such cases were indirectly asserting "Member States' rights". After all, had their claims succeeded and the EU legislation been declared invalid, it would have resulted in the Member States being free to once again regulate the maximum tar content of cigarettes or the acceptable nutrients in certain supplements. To use Choper's terminology, the claimants in national proceedings who succeeded in having national courts refer their arguments to the CJEU "concede that one of the two levels of government has power to engage in the questioned conduct; the issue is simply whether the particular level that has acted is the constitutionally proper one. ${ }^{\prime 3}$

By engaging with Article 5 TEU arguments and reviewing EU legal acts against the EU's federalism principles in cases that originated in national courts, the CJEU has evidently not declared such challenges non-justiciable. On the one hand, this is unsurprising given the abstract nature of validity review as provided for by the preliminary ruling procedure and the CJEU's obligation to review of all EU legal acts under Article $263 \mathrm{TFEU}$. On the other, as was argued above, it is clear that the origins (and in some cases the very wording) of these federalism challenges originate in the claims proffered by individuals.

This is even more intriguing when one considers that these assertions of national regulatory autonomy by natural/legal persons may be at odds with the view of the Member States(s) in which they conduct their business. Indeed, the claimants in British American Tobacco were established in the UK (and conducted business throughout the Union) when contending that the EU legislation in question infringed the EU's federalism principles enshrined in Article $5 \mathrm{TEU}$. Despite their impassioned plea for the continued regulatory autonomy of the Member States in sensitive policy areas, however, the United Kingdom government itself did not agree. Instead, it first voted for the EU legislation in question in the Council and subsequently argued that that legislation complied with the proportionality and subsidiarity principles in litigation before the CJEU. ${ }^{84}$

Again, the key question posed here is whose rights are recognised by the Court in such cases and how are they articulated, calibrated and balanced?

82 British American Tobacco, supra note 25, para. 174.

83 Choper, supra note 52 , p. 1555.

84 British American Tobacco, supra note 25, para. 176. 


\section{Recent Developments in EU Federalism: Whose Rights are Being Articulated, Identified and Balanced?}

Unfortunately, the terseness of the Court's reasoning in the cases cited above makes it rather difficult to ascertain whose rights and interests were being articulated, identified and ultimately balanced whenever EU legislation was reviewed for compliance with the principles enshrined in Article 5 TEU. ${ }^{85}$ Whilst it has been submitted that natural and legal persons seemed to be articulating some conception of Member States' rights in cases like BAT and Alliance for Natural Health, the Court never explicitly tackled this question. Furthermore, despite calls from certain academic quarters to do so, the CJEU was hesitant to expressly review whether EU legislation had unnecessarily restricted national regulatory autonomy. ${ }^{86}$ Indeed, it has been said that the Court's case law in this area fails to clearly address the balance struck by the EU legislature between the added value to the EU of acting on the federal level, on the one hand, and any possible harm to national interests, on the other. ${ }^{87}$ Instead, cases continued to turn on the classic argument that EU legislation went beyond what was necessary or imposed a disproportionate burden upon individuals and companies. ${ }^{88}$

That being said, it is submitted that the question of whose rights are really at stake in litigation before the CJEU has taken on increased importance following the recent articulation of some novel, federalism-type arguments by certain EU Member States. These cases involve Member States seeking to directly annul EU legislation on the grounds that the latter has unnecessarily restricted national autonomy, or that the impact upon the Member States is disproportionate to the purported gains of EU level action. ${ }^{89}$ These novel developments lead one to consider whether it is possible that similar arguments might soon be made by individuals via the preliminary reference procedure? Once again, the question is whether the claimants in such cases would in fact actually be articulating some conception of "Member States' rights" to continued national

85 Ibid., paras. 182-185; See also Case C-84/94 United Kingdom of Great Britain and Northern Ireland v. Council, ECLI:EU:C:1996:431, paras. 46-47, 55.

86 Groussot and Bogojević, supra note 65, p. 249; Schütze, supra note 7, pp. 262-263; G Davies, 'Subsidiarity: The Wrong Idea, in the Wrong Place, at the Wrong Time', 43 Common Market Law Review (2006) p. 63.

87 Groussot and Bogojević, supra note 65, p. 249.

88 Case C-210/o3 Swedish Match AB and Swedish Match UK Ltd v. Secretary of State for Health, EU:C:2004:802; British American Tobacco, supra note 25.

89 Groussot and Bogojević, supra note 65, p. 249. 
regulatory autonomy? ${ }^{90}$ As we shall see, claims of this nature pose difficult questions for the CJEU which go to the very core of the question of whose rights and interests are being promulgated and balanced in such cases.

\subsection{Federal Proportionality and the Tobacco Products Litigation}

The first example of this novel type of federal proportionality challenge is Poland v. Parliament and Council (Tobacco Products), where Poland (supported by Romania) challenged the validity of the Tobacco Products Directive on both subsidiarity and proportionality grounds. ${ }^{91}$

The EU legislation in question sought, inter alia, to ban the placing on the internal market of menthol and other flavoured tobacco products. In the view of Poland and Romania, the social and economic costs of such a prohibition - in terms of lost jobs and revenue - rendered the EU legislation disproportionate; particularly with regards to Member States like Poland where there was a significant industry in the manufacturing and consumption of flavoured tobacco products. ${ }^{92}$ Fundamentally, therefore, the claim was one of federal proportionality in that Poland and Romania were asking whether the "importance of the Union measure [was] sufficient to justify its net effect on Member States"? 93

In response, the Court held that "the mere fact an EU legislative act is likely to affect one Member State more than others" cannot be contrary to the principle of proportionality, provided the different stages of that principle have been complied with. ${ }^{94}$ Accordingly, the Court would consider whether the EU legislation was "appropriate for attaining the legitimate objectives pursued by the legislation at issue and do not exceed the limits of what is necessary in order to achieve those objectives; when there is a choice between several appropriate measures, recourse must be had to the least onerous, and the disadvantages caused must not be disproportionate to the aims pursued."95

9o For a discussion of the ways in which subsidiarity and proportionality may be read and applied together within the context of EU federalism see Ibid., pp. 236-237.

91 Poland v. European Parliament and Council, supra note 12.

92 Ibid., para. 73 .

93 See J. Hettne and F. Langdal, 'Does Subsidiarity Ask the Right Question?', Think GlobalAct European (TGAE) (2011) p. 354, <http://www.sieps.se/sv/publikationer/tgae-2011-thecontributionof-16-european-think-tanks-to-the-polish-danish-and-cypriot-trio-presidenc $>$, visited on 1 April 2020.

94 Poland v. European Parliament and Council, supra note 12, para. 103.

95 Ibid., para. 103; Case C-5/16 Poland v. Parliament and Council (MSR), ECLI:EU:C:2018:483, para. 167 . 
Notably, no reference is made in this formulation of the proportionality principle to the disproportionate impact that the legislation had upon individual rights or economic interests. Instead, within the context of an argument by a Member State that EU legislation imposed disproportionate economic and social costs upon them, the CJEU would consider whether the disadvantages caused were disproportionate to the aims pursued. In conducting this form of federal proportionality review, the Court swiftly concluded that the balance struck between the objectives of the Directive and relevant interests in all Member States was not disproportionate. ${ }^{96}$

Unfortunately, the reasoning on these matters was rather brief. There was no clear identification of whose rights and interests were to be considered and balanced in the case. ${ }^{97}$ By referring to the balance struck between the different interests involved in all EU Member States, on the one hand, and the objectives of EU legislation, on the other, the reasoning could be interpreted as "balancing the added value to the Union against any possible harm to national interests" ${ }^{98}$ Matters were clarified to a certain extent in the recent Market Stability Reserve case, where the CJEU held that "the legislature does not have to take into consideration the particular situation of a Member State where the EU measure has an impact in all Member States and requires that a balance between the different interests involved is ensured, taking account of the objectives of that measure". ${ }^{9}$

In both cases, the Court sets up a balance between unspecified "different interests" pertaining to the situation in all EU Member States, on the one hand, and the objectives of the EU legislation, on the other. ${ }^{100}$ It follows that individual Member States will be unsuccessful in making federal proportionality challenges to EU legislation if their claim relates solely to their own national circumstances. That said, the door is now open to challenging EU legislation on the grounds that, on balance, it disproportionately restricts national regulatory autonomy (plural) or imposes excessive costs on the Member States (collectively).

In light of these developments, it seems possible that individuals may raise similar arguments when seeking to indirectly contest the validity of EU legislation via the preliminary reference procedure. Given the somewhat opaque reasoning of the CJEU to date, it is unclear how the Court would go about

96 Poland v. European Parliament and Council, supra note 12, para. 103.

97 Ibid., para. 103.

98 Groussot and Bogojević, supra note 65, p. 249.

99 Poland v. Parliament and Council (MSR), supra note 95, para. 167.

100 On this point see Estonia v. Parliament and Council, supra note 11, para. 39. 
conducting a balancing exercise whenever a challenge to EU legislation on federal proportionality grounds stems indirectly from a natural/legal person rather than directly by a Member State.

On one view, the source of the challenge to EU legislation is irrelevant. In both direct and indirect actions, the CJEU's task is simply to review the validity of EU legislation in the abstract, with the consequence that such legislation will be invalidated if it breaches the EU's federalism principles enshrined in Article 5 TEU. The identity of the parties bringing such claims is irrelevant to resolving the legal question of whether EU legislation places disproportionate social or economic costs on the Member State(s).

That said, there is something puzzling about the prospect of the CJEU invalidating EU legislation on such "federalism" grounds when the claim is being articulated by individuals. This point is made with even greater force when one considers that, much like in Vodafone and BAT considered above, the Member State(s) concerned might actually support the contested EU legislation and wish to defend its validity. If individuals can indirectly challenge the validity of EU legislation on the grounds that it disproportionately impacts certain Member States - but those same Member States actually support the measure - whose rights and interests are really at stake here?

The purpose here is not to resolve these questions one way or the other. Rather, it is to highlight the potential problems that may arise in circumstances where individuals appear to be articulating "Member States' rights" rather than any particular right or interest of their own. In line with the concerns expressed by Choper above, situations may arise in which individuals succeed in invalidating EU legislation and thus vindicating national regulatory autonomy, despite such vindication being contrary to the express wishes of the Member State(s) concerned. As we shall see, this could lead to individuals articulating some potentially explosive claims concerning "Member States' rights" before the Court.

\subsection{A Novel Approach to Subsidiarity Review}

The potential difficulties that could arise in cases of this nature are even easier to identify when one considers recent developments in the CJEU's subsidiarity jurisprudence. In Estonia v. Parliament and Council, for example, Estonia challenged the validity of EU legislation regulating certain financial reporting obligations of small and medium sized businesses. In Estonia's view, the EU legislation infringed both the principles of subsidiarity and proportionality on the grounds that, inter alia, the EU legislature did not take account of its particular situation as a Member State which is advanced in electronic 
administration. ${ }^{101}$ In particular, Estonia's system of accounting and reporting for small and medium sized businesses was more advanced than the EU wide system it now had to adopt by virtue of the Directive. Therefore, Estonia claimed that the EU legislature had not considered its situation when legislating, the result of which was that its national regulatory autonomy had been disproportionately restricted by the EU legislation in question.

In response, the CJEU held for the first time in its history that:

The subsidiarity principle is not intended to limit the EU's competence on the basis of the situation of any particular Member State taken individually, but requires only that the proposed action can, by reason of its scale or effects, be better achieved at EU level, given its objectives listed in Article $3 \mathrm{TEU} . . .102$

Then, in another first for the Court, it concluded that:

It follows that the principle of subsidiarity cannot have the effect of rendering an EU measure invalid because of the particular situation of a Member State, even if it is more advanced than others in terms of an objective pursued by the EU legislature, where, as in the present case, the legislature has concluded on the basis of detailed evidence and without committing any error of assessment that the general interests of the European Union could be better served by action at that level..$^{103}$

Despite rejecting Estonia's arguments in the case, this novel aspect to the CJEU's reasoning suggests that EU legislation may infringe the principle of subsidiarity whenever the EU legislature does not base its subsidiarity calculus upon detailed evidence. Similarly, one can envisage subsidiarity challenges on the grounds that such conclusions were reached following an error of assessment by the EU legislature. This has been confirmed in subsequent case law. ${ }^{104}$

Based on the abovementioned example of Alliance for Natural Health, it seems possible for individuals to make similar claims when indirectly contesting the validity of EU legislation through the preliminary reference procedure. Thus, individuals may seek the annulment of EU legislation on the grounds that the EU legislature's conclusions as to better achieving an objective through

\footnotetext{
101 Ibid., paras 23, 41.

102 Ibid., para. 53; Poland v. European Parliament and Council, supra note 12, para. 119.

103 Estonia v. Parliament and Council, supra note 11, para. 54.

104 Poland v. European Parliament and Council, supra note 12, para. 114.
} 
EU level action was based on an error of assessment. In other words, the case for EU level action is unpersuasive or based on inaccurate assessments, with the consequence that matters should be left to the Member States to regulate. Again, this appears to be an example of individuals asserting Member States' rights to national regulatory autonomy, thus bringing the question of whose rights and interests are at stake in these cases into sharp relief.

\subsection{Invoking the National Identity of the Member States in Federalism Disputes}

The final point to consider when analysing the role of individuals in articulating Member States' rights in federalism disputes is the impact of Article 4(2) TEU. According to that provision, which was added by the Treaty of Lisbon, the EU must respect the national identities of the Member States "inherent in their fundamental structures, political and constitutional, inclusive of regional and local self-government. It shall respect their essential State functions, including ensuring the territorial integrity of the State, maintaining law and order and safeguarding national security ..."

To appreciate the potentially explosive impact that this provision could have in the future, it is necessary to return to the abovementioned Tobacco Products case. As part of that litigation, Advocate General Kokott made a rather important statement of legal principle that has not yet gained much attention in the literature. When dealing with Poland's argument that the EU legislation in question infringed the principle of subsidiarity, AG Kokott noted that "a stricter judicial review of subsidiarity may be necessary where an EU measure exceptionally affects matters of national identity of the Member States (Article 4(2) TEU).".05

Following this reasoning, Member States may now argue that EU legislation infringes the principle of subsidiarity because it affects matters of national identity, such as their fundamental political and/or constitutional structures. Furthermore, if a convincing challenge of this sort were to be raised, the Court would subsequently engage in high intensity subsidiarity review of the EU legislation in question. Rather than merely checking whether the EU legislature relied on an adequate factual basis and did not commit a manifest error of assessment, the CJEU would engage in close scrutiny of the contested EU legislation to ascertain whether it impacted national identity in some way. ${ }^{106}$

The fact that an argument of this nature might be made inevitably places the Court in the position of having to consider whether the justification for

105 AG Kokott in ibid., para. 148.

106 Ibid. 
action on the EU level outweighs the impact upon the national identity of the Member States. This would place the CJEU in the uncomfortable position of potentially having to rule on the content and scope of aspects of national identity. It could also require the Court to utilise the subsidiarity (and perhaps federal proportionality) principles to review the balance struck by the EU legislature between the pursuit of EU objectives and the alleged effect upon aspects of national identity.

But even before we get to the balancing exercise in such a case, one must consider two key questions. First, considering the Court's findings in the abovementioned case of Estonia v. Parliament and Council, must such national identity arguments be made with regards to the impact that EU legislation has upon a plurality of Member States? Or would it have been possible in Poland v. Parliament and Council, for example, for Poland to have argued that the EU ban on flavoured tobacco products infringed aspects of Polish national identity specifically? Identifying whose rights and interests are at stake in such cases would seem to be necessary before the CJEU could then effectively review whether EU legislation had indeed infringed the EU's federalism principles and/or Article 4(2) TEU in a particular case. Second, what would happen if such an argument originated not in a direct action by a Member State, but indirectly at the behest of an individual through the preliminary reference procedure? Based on the case law and arguments developed above, indirect challenges to the validity of EU legislation could indeed be brought by individuals on the grounds that that legislation infringed aspects of national identity as protected by Article 4(2) TEU. If the preliminary reference procedure simply provides for abstract review - and such abstract review now entails claims of subsidiarity, federal proportionality and Article 4(2) national identity - claims of this nature must be possible.

And it is here that the question of whose rights and interests are really at stake in such proceedings is perhaps at its most profound. Notwithstanding the fact that, formally speaking, it is national courts who pose validity questions to the CJEU, does it really make sense to allow individuals to put such potentially explosive questions to the CJEU? On what grounds can we say that an individual is competent to articulate aspects of the national identity of a single Member States and/or plurality of Member States? Moreover, how should the Court respond to claims by individuals that EU legislation is invalid for infringing aspects of national identity, particularly when the Member State(s) concerned take the contrary view? To put it at its most bizarre, could a UK-based company like Vodafone argue that EU legislation was invalid because, inter alia, it impermissibly encroached upon aspects of the national identity of the Baltic Member States of the EU? One possible solution to these questions, it 
is submitted, would be to conceptualise such challenges to EU legislation in much the same way as Choper would in the United States; namely, that these cases are really about the abridgement of "Member States' rights" since they entail "states' rights claims [being] asserted by private citizens". 107

\section{Conclusion}

This article has considered whose rights and interests are really being articulated and balanced in cases where individuals seek to indirectly challenge the validity of EU legislation on Article 5 TEU federalism grounds. Taking inspiration from federalism scholars in the United States, it was argued that, in certain circumstances, indirect challenges to EU legislation by individuals entails an articulation of "Member States' rights". This is most notable in cases where individuals and companies have contended, via the preliminary reference procedure, that EU legislation unjustifiably interfered with the powers of the Member States to regulate sensitive areas involving health, social and economic policy. ${ }^{108}$ In such cases, aspects of the challenge raised by the claimants in national courts do not entail any individual right or interest. Rather, by arguing that EU legislation infringes subsidiarity and/or proportionality, the crux of the claim is for the restoration of the Member States' right to regulate a particular matter. As such, they should be understood as entailing a "states' rights challenge to a federal enactment that is brought by a private person".109

However, based upon the reasoning of the CJEU to date, it is unclear whether the identity of the parties raising federalism challenges (i.e. Member States directly or natural/legal persons indirectly) has any impact on the manner in which validity review is conducted. Indeed, it is incredibly difficult to identify whose rights and interests are being articulated and balanced in federalism challenges to EU legislation raised indirectly by natural/legal persons.

Against this background of ambiguity, this article has analysed some contemporary developments in the CJEU's federalism jurisprudence which could, in time, pose difficult questions about how different rights and interests should be considered within the context of federal proportionality review of EU legislation. In this regard, it has recently been argued that EU legislation is invalid for placing a disproportionate economic and/or social burden upon certain Member States. Moreover, members of the CJEU have postulated that

107 Choper, supra note 52, p. 1577, 1588.

108 Alliance for Natural Health, supra note 70; British American Tobacco, supra note 25.

109 Choper, supra note 52, p. 1577. 
high-intensity, strict subsidiarity review of EU legislation would be necessary in circumstances where EU legislation impinges upon the national identity of the Member States.

In light of these developments, the crucial question to be considered is whether individuals may indirectly raise similar claims in the future? If so, how should the Court deal with situations in which individuals (indirectly) allege that EU legislation should be annulled since the purported benefits of EU wide action are outweighed by the negative economic and social impacts in the Member States? Even more controversially, how should one conceptualise arguments raised by individuals through the preliminary reference procedure to the effect that EU legislation is invalid for impermissibly encroaching upon an aspect of national identity as enshrined in Article 4(2) TEU?

Irrespective of whether one agrees with conceptualising these challenges as an articulation of "Member States' rights", it is clear that the question of whose rights and interests are really at stake in such cases is one that is likely to require further consideration in the not too distant future. 